\title{
Notes on the vocalizations of Sultan Tit (Melanochlora sultanea)
}

Peter Boesman

In the following we briefly analyze and compare voice of the four races of Sultan Tit (Melanochlora sultanea). We also try to quantify the extent of any vocal differences using the criteria proposed by Tobias et al. (2010), as a support for taxonomic review. We have made use of sound recordings available on-line from Xeno Canto (XC).

Comparison of song-like vocalizations among races:

\section{Race sultanea}
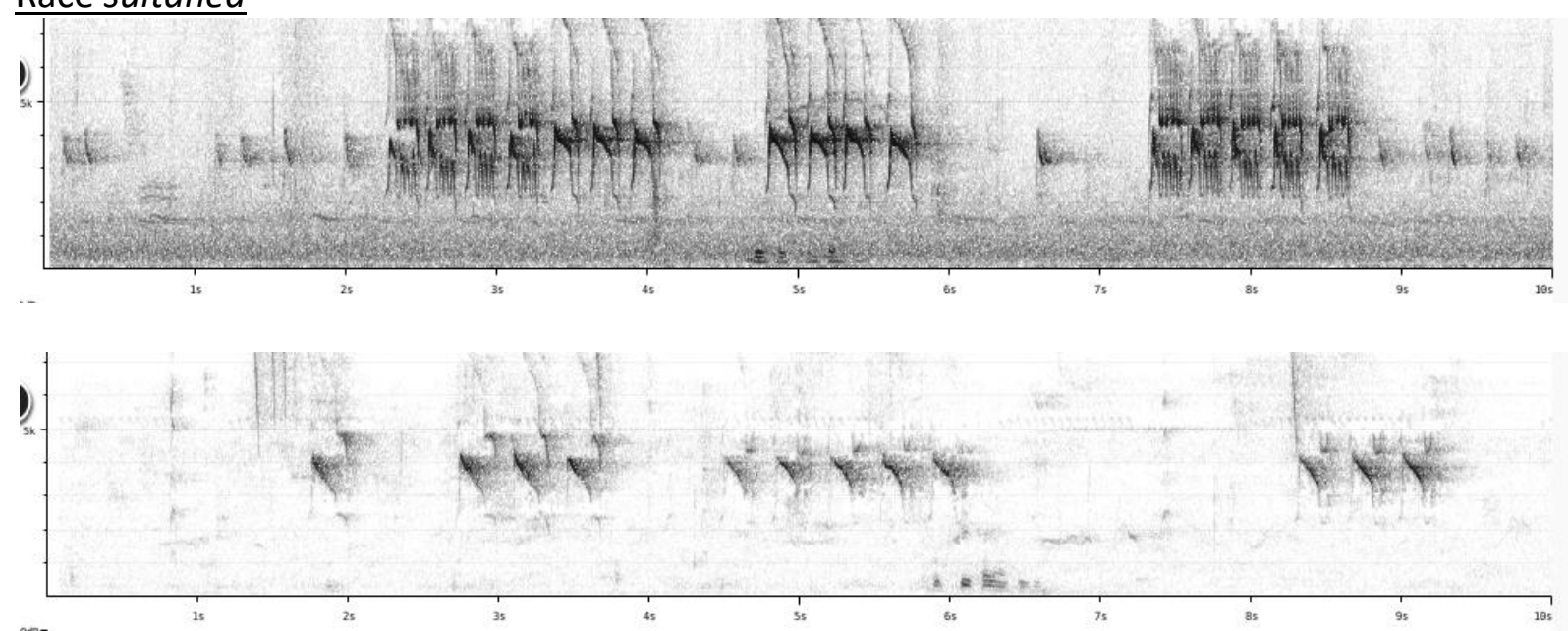

Race flavocristata
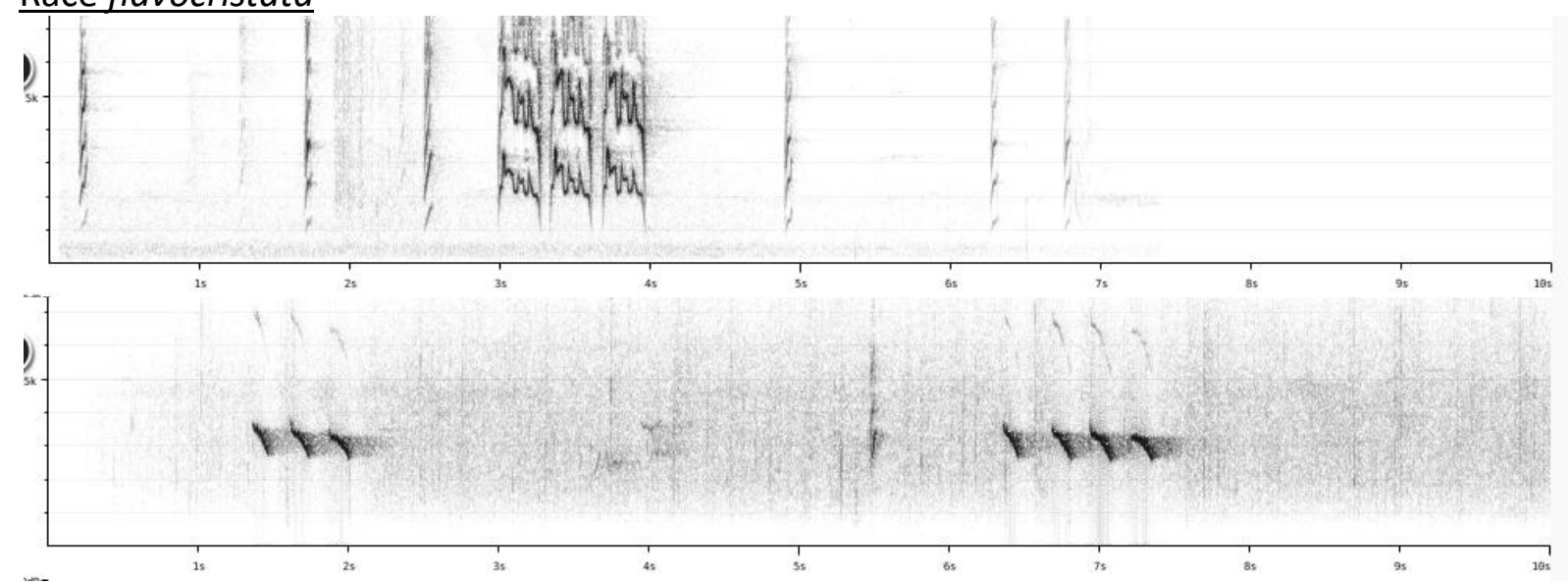

$\underline{\text { Race seorsa }}$

(Vietnam)

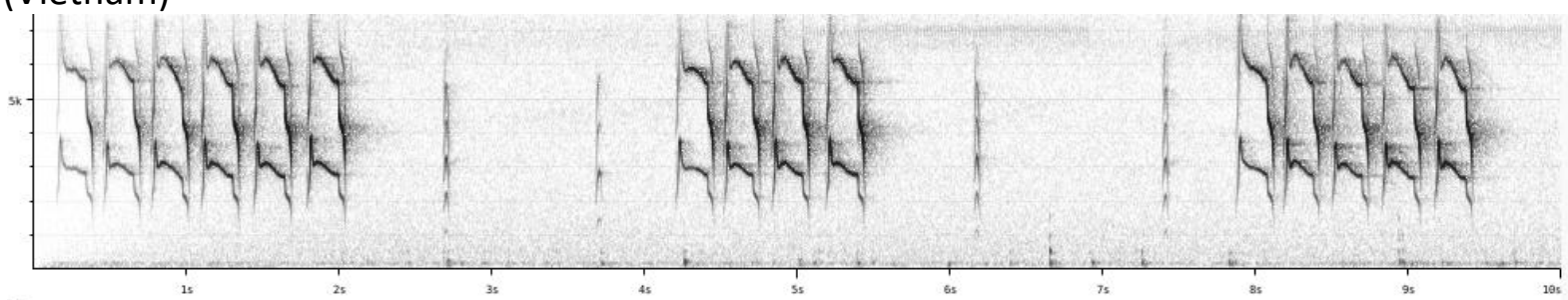




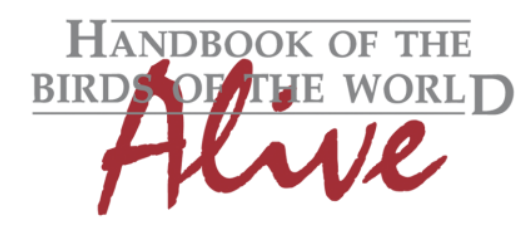

\section{ORNITHOLOGICAL NOTES}
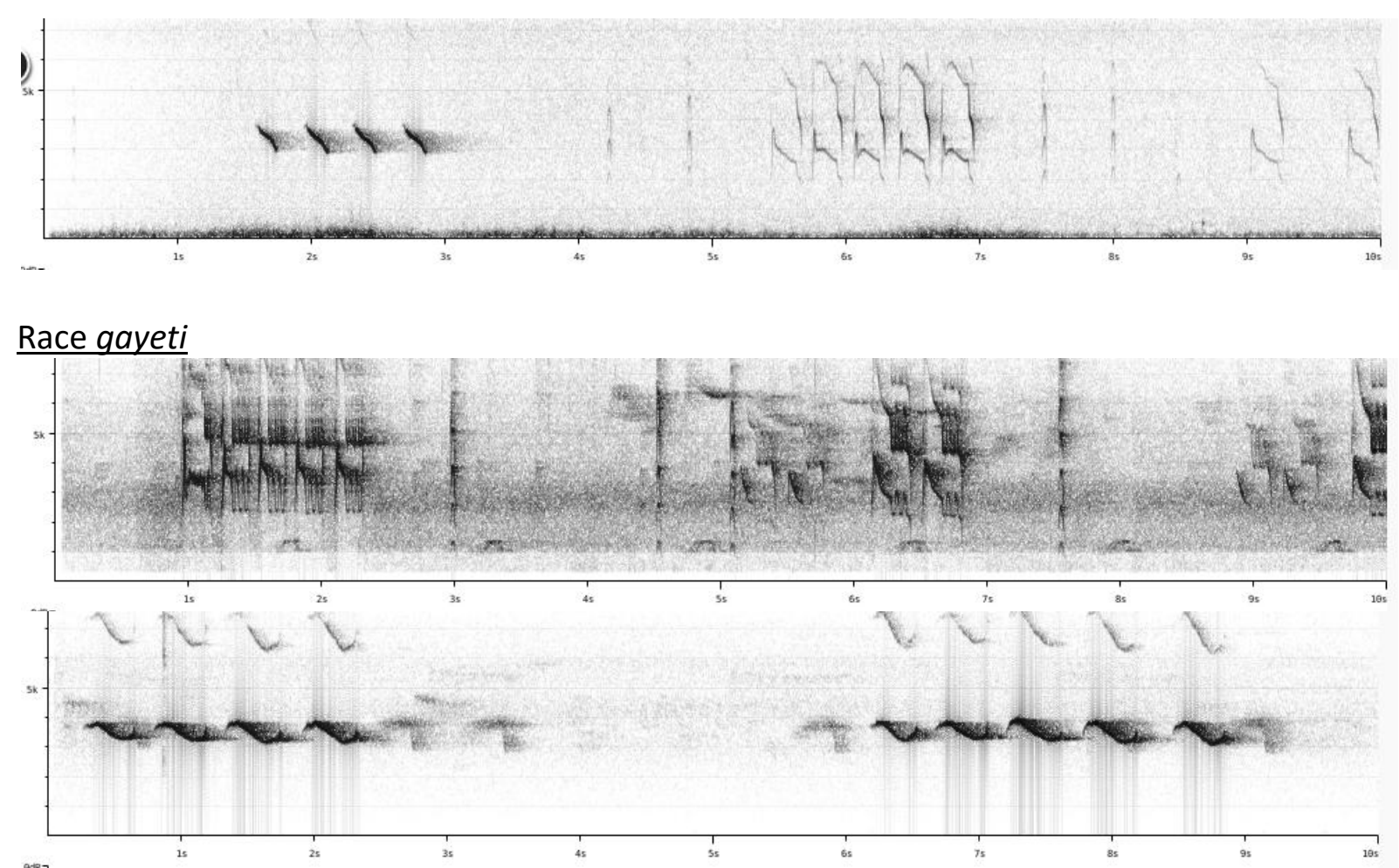

It would seem that all races have two song-like vocalisations, a series of complex descending rather squeaky notes, and a short series of more whistled notes.

The first vocalization is about identical among all races (compare e.g. sonograms of gayeti with sultanea).

The second vocalization seems to differ somewhat in the case of gayeti $(n=1)$. It is unclear how 'important' this vocalization is, e.g. is this the true territorial song or not. There is only a single recording of this vocalization for gayeti, but all homologous vocalizations of other races are of a descending whistle, while gayeti seems to utter longer whistles with upslurred ending. More recordings are needed to confirm whether this is indeed a consistent vocal difference.

This note was finalized on 4th February 2016, using sound recordings available on-line at that moment. We would like to thank in particular the sound recordists who placed their recordings for this species on XC: Patrik Åberg, Nick Athanas, Brian Cox, David Edwards, David Farrow, David Fischer, Ross Gallardy, Greg Irving, Frank Lambert, Yong Ding Li, Hans Matheve, Arnold Meijer, Mike Nelson, Sander Pieterse, Mathias Ritschard, Ramit Singal, Klemens Steiof, Nick Talbot, Bram Vogels and Arend Wassink.

\section{References}

Tobias, J.A., Seddon, N., Spottiswoode, C.N., Pilgrim, J.D., Fishpool, L.D.C. \& Collar, N.J. (2010). Quantitative criteria for species delimitation. Ibis 152(4): 724-746. 


\section{Recommended citation}

Boesman, P. (2016). Notes on the vocalizations of Sultan Tit (Melanochlora sultanea). HBW Alive Ornithological Note 216. In: Handbook of the Birds of the World Alive. Lynx Edicions, Barcelona. (retrieved from http://www.hbw.com/node/932174 on 6 September 2016). 